
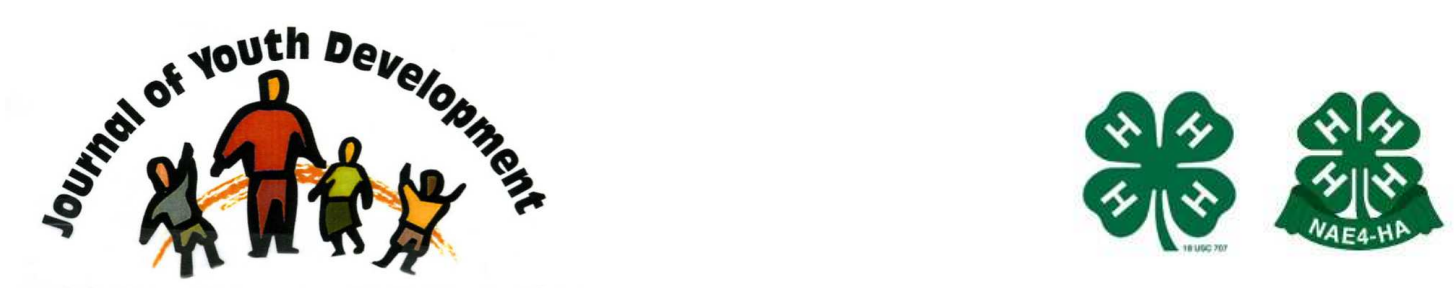

Bridging Research \& Practice

\title{
Measuring the Influences of Youth Participation in Ohio 4-H Camps
}

\author{
Greg Homan \\ Ohio State University Extension \\ Van Wert, Ohio \\ homan.14@cfaes.osu.edu \\ Jason Hedrick \\ Ohio State University Extension \\ hedrick.10@cfaes.osu.edu \\ Jeff Dick \\ Ohio State University Extension \\ dick.7@cfaes.osu.edu
}




\title{
JOURNAL OF YOUTH DEVELOPMENT \\ bridging research and practice

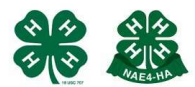

Volume 3, Number 1, Summer 2008

Article 080301RS003

\section{Measuring the Influences of Youth Participation in Ohio 4-H Camps}

\author{
Greg Homan, Jason Hedrick and Jeff Dick \\ Ohio State University Extension
}

\begin{abstract}
Findings from a multi-component 4-H camp marketing and enrollment study of Ohio 4-H camps are highlighted. Significant influencers on the camp enrollment decision (parents, other adults, peers, siblings, and the respective camper) are evaluated as well as the effectiveness of various marketing techniques. The data found in this study indicates that the decision to enroll in camp is most influenced by the respective 4-H camper; however parents are also a strong factor in the choice to participate in 4-H camps. Alumni parents report significantly higher influence in the camp enrollment decision than those parents who are not alumni of 4-H. Personal methods of promoting camps were rated the most effective in reaching potential camp audiences.
\end{abstract}

\section{Background}

4-H camping is an extracurricular activity choice that involves hundreds of thousands of youth annually in a youth development experience under the direction of 4-H programs nationwide. According to National 4-H Enrollment Statistics (USDA, 2005), 299,297 youth participated in overnight 4-H camps in 2005. Fifty-eight percent of these youth were female and $42 \%$ were male. During the same time period Ohio $4-\mathrm{H}$ camps reached 31,709 youth (59\% female and $41 \%$ male) (Ohio State University Extension, 2005). Typical 4-H camps are operated for four to five days offering broad youth development experiences, outdoor education and life skill programming. Efforts usually are directed by a mixture of professional staff with youth and adult volunteers.

Why 4-H camp participation is valuable?

Youth participation in leadership activities and special interest clubs has been positively related to student academic achievement, school engagement, and educational aspirations (Lamborn, et al (1992). Bartko \& Eccles (2003) found adolescents that participated in a number of constructive, organized activities, combined with relatively little participation in passive, 
unstructured activities showed healthy behavior and development as well as good academic performance. Involvement in 4- $\mathrm{H}$ activities can be attributed to decreased deviance and increased positive skill development. Astroth \& Haynes (2002) found that youth involved in after-school programs (such as 4-H) were less likely to be involved in a wide range of at-risk behaviors such as drinking alcohol, shoplifting, damaging property, smoking, or abusing other drugs. They also found that 4-H'ers, when compared to non-4-H youth, are more likely to succeed in school, be more involved as leaders in their communities, help others in their community, and be seen as a role model by other kids. Research evaluated the impact of participation in 4-H camping programs has revealed that 4-H campers grow socially and develop life skills such as personal responsibility, positive decision-making, and taking initiative(Arnold, et.al, 2005; Garst, B. \& Bruce, F.A., 2003).

\section{Retaining current 4-H participants}

According to Thompson (1998), "The three reasons non re-enrollees ranked as most important in their decision to not re-enroll were (1) they were too busy; (2) other activities were more important; and (3) they did not have enough time for 4-H activities." The researcher concluded that it is not how many activities teens are involved with, but how important 4- $\mathrm{H}$ is to them in comparison to the other activities that determine whether they remain in 4- $\mathrm{H}$. Thompson (1998) reports "Ohio 4-H has had little problem attracting preteen 4-H members to the program, but has experienced difficulty retaining the members through the teen years." Thompson (1998), citing a study by Nichols (1973) reported that "members with high participation levels were less likely to drop out and that participation levels were inversely related to their age at initial enrollment." Thompson also cites Beasley (1980) stating "Peer influence is an important factor in recruitment and retention." In Leeds' (1997) study of 4-H members in Union County, Ohio, she found "The high school age participants expressed frustration that 4-H sometimes felt as though it was focused toward younger members." Enrollment trends in 4-H camping reflect these perceptions as camp participation is skewed with a greater participation rate found by youth under the age of 13 (Ohio 4-H Blue Ribbon Youth Enrollment ES-237 Report, 2007).

\section{Why youth participate}

The motivation for youth to participate in free-time activities such as camp /or 4-H is conceptualized by Deci \& Ryan (1985) using the self-determination theory. They explain the participation of individuals is understood by their natural tendency to take part in experiences to meet their needs to seek out new experiences and pursue interests. They rate types of motivation within a scale ranging from "amotivation" to intrinsic motivation. Those described as "amotivated" may be reacting to lack of control, such as a parent forcing their participation. Those on the other end of the scale (intrinsically motivated) are participating due to the inherent satisfaction of the activity and enjoyment of participating. According to the Eccles' expectancy-value model (Eccles \& Harold, 1991), youth respond to the varying levels of support that parents provide to activity choices that youth have. Those activities that parents believe their children are suited for, or can be successful in, will be provided more support by the parents.

Research has found that gender can be predictive of youth extracurricular activity involvement. Mahoney, et al. (2003) found consistently higher participation rates by girls in extracurricular activities. Friends have been found to have a stronger influence on participation choice for girls (Raymore, et al, 1994). Higher socioeconomic status not only directly enables youth to financially participate in activities, but has been related to their confidence and approach to trying new things (Raymore, et al, 1994). Current enrollment data for Ohio 4-H camps reveals 
a skewed enrollment rate with significantly larger number of female youth participating. A family financial status may play a major factor in the decision to enroll in 4-H camping programs and may applied in the nature and strength of parental influence in the camp enrollment decision.

\section{Peer influence}

The impact of the friend group, or peers, can be a powerful influence in a young person's life. Learning how to interact with others, supporting and identifying interests, and developing autonomy without control of parents or adults are roles of the peer group (Castrogiovanni, 2001). The social group or peer structure endorsement of an activity is positively related to participation in extracurricular activities and non-school clubs (Huebner \& Mancini, 2003). Lingren (1995) found that peer influence can keep youth active in extracurricular activities ranging from religious activities to $4-\mathrm{H}$ clubs and school sports. When evaluating the impact of peers, Black (2002) suggests that peer pressure is a stronger predictable factor during the transition from childhood to adolescence than in preteen and teen years.

In a study evaluating the nature of parent and friend relationships within adolescents, Laursen, et al. (2000) found that early adolescents report strong peer and parental reciprocity or mutuality and cooperation. As youth aged, particularly with females, the level of reciprocity became greater with peers than with parents. Rennekamp (1990), studying decision-making practices of teens found, " $51 \%$ of respondents indicated friends had greater influence, while the remaining $49 \%$ cited parents as having more." However, the impact of peer pressure during later adolescence is described as overestimated as youth make more autonomous and personal decisions with less direct influence of the peer group (Black, 2002).

\section{Parental influence}

Parents are important socializing agents, providing encouragement for their children to get involved in extra-curricular activities (Brustad, 1988). Parental endorsement of activity choices has been related to higher levels of participation (Huebner \& Mancini, 2003; Mahoney \& Stattin, 2000). Parental warmth towards their children and parental community involvement were both found to be positively correlated to youth involvement in extracurricular activities (Fletcher, Elder \& Mekos, 2000). Eccles et al. (1993) developed an expectancy-value model, connecting parental behavior toward a respective activity and the involvement of youth in that activity choice. Youth tend to follow a similar value structure of their parents, choosing to take part in those activities that their parents support.

In a study of fifth through eighth graders in Arizona, Hultsman (1993) found that parental influence was perceived as a greater influence than other groups (significant other adults and peers) in the decision not to join an activity. The constraints such as transportation and cost of participation can be influential in the decision of parents to restrict involvement of their youth in a potential activity. Howard \& Madrigal (1990) found that the decision to participate in an extracurricular activity is first pre-screened by mothers. They found that mothers made early decisions about potential activities before allowing children to be involved in final decisionmaking processes. According to Hultsman (1993), it is suggested that marketing efforts of programs should shift from parents toward youth as youth age they gradually become stronger influencers in the purchasing of leisure experiences.

Marketing 4-H Camps

According to Chappell (1994), effective marketing doesn't just happen; it is a planned process without a specific easy answer. Marketing Extension programs involved identifying the target 
audience, designing the message to reach them, and getting the message to them in a way that causes them to choose to take action (Skelly, 2005). In the past it may have been enough to simply offer quality programs and wait for the audience to walk through the door; now Extension staff needs to reach out to busy potential clientele seeking their participation.

A study conducted by Wingenbaugh, et al. (2000) evaluated marketing strategies for recruiting 4-H members in West Virginia. The top factors influencing respondents to join $4-\mathrm{H}$ included: sounded fun $(65.1 \%)$, friends were in it $(61.7 \%)$, to meet new friends $(56 \%)$, parent or guardian wanted me to join (49.1\%), and family was already involved $(41.1 \%)$. When evaluating youth responses rating the importance of individual marketing methods used to secure their membership as a 4-H club member the highest responses were related to friends or classmates informing them about 4- $\mathrm{H}$, information on the internet, and 4-H-related displays. Moderately rated responses were related to other adults (non parents) telling them about 4- $\mathrm{H}$, radio/video promotions, and parents telling them about $4-\mathrm{H}$. Relatively low-rated methods for attracting youth were letters sent home, newspaper advertisements and 4-H promotional items (Wingenbaugh, et al., 2000).

\section{Research objective}

To date, little research has been done evaluating the nature of the camp enrollment decision and the effectiveness of camp marketing techniques. The goals of this research are to determine the nature of significant influencers on who decides to participate in 4-H summer camps in Ohio and to evaluate the effectiveness of various marketing techniques used to reach the decision makers in the camp enrollment decision.

\section{Methods and Procedures}

The researchers developed a multi-component on-line based survey instrument. A stratified random sample of counties in Ohio was selected to assure representation from each of the 12 Ohio camp facilities. After obtaining OSU IRB approval, parents of participating campers (712) were invited to complete the on-line instrument through email invitation with 273 participants. Three survey reminders were sent to parents encouraging their participation. One participant per county was awarded a $\$ 25$ gift certificate, at random, to recognize their involvement.

The survey consisted of multiple Five-point anchored Likert-type questions, developed to measure level of influence (from "No Influence" to "High Influence"), level of effectiveness (from "Not Effective" to "Very Effective"), level of importance ("Not Important" to "Very Important") degree of improvement ("Not at All" to "Very High") and level of agreement (from "Strongly Disagree" to "Strongly Agree"). Various demographic questions were also included in the survey to analyze subsets of the population and ensure diversity in sample response. Descriptive methods were used to analyze group response rates. Means score tests were run to compare variable responses. Cronbach's Alpha was used to determine the reliability of this instrument at .719.

The typical respondent to our survey was the child's mother, with $88 \%$ of those responding. Fathers completed $10 \%$ of surveys and legal guardians $2 \%$ of the sample. Reponses represent thirteen counties across the state of Ohio with $40 \%$ of families residing on farms, $44 \%$ in small towns or other rural locations, and $17 \%$ living in larger towns or cities. Results reflect $36 \%$ of male campers and 64\% female campers. Age range was from 8-14 years of age. Of those completing surveys, $36 \%$ indicated that their child attended camp for the first year, $20 \%$ their 
second year, and $44 \%$ three years or more. The typical family income was $\$ 40,000$ to $\$ 80,000$ and the typical camp fee paid to participate in a summer $4-\mathrm{H}$ camp was $\$ 75$ to $\$ 150$.

\section{Research Questions}

1. How strong is the influence in the camp enrollment decision (parent, child, peers, other parents, club advisors, or siblings)?

2. Are there differences in the nature of influence or the decision to enroll in summer 4-H camps based on child age?

3. Does the gender predict differences in the nature of significant influence in the camp enrollment decision?

4. Are there differences in the influence of camp enrollment of children based on the alumni status of their parents?

5. What methods of marketing are rated most effective in reaching 4-H camp families?

\section{Results}

\section{How strong is the influence in the camp enrollment decision (parent, child, peers, other} parents, club advisors, or siblings)?

The nature of influence from parents, the respective child, friends, and other adults on the camp enrollment decision was evaluated. The highest influencers, as reported by the parent, were the respective child, followed by the parent (Table 1). When rating the influence of their child in the camp enrollment decision $90 \%$ of parents rated their child as having a high or moderately high influence. The parents themselves rated their relative influence in the camp enrollment decision highly as well, with $76 \%$ selecting moderately high to high ratings on the influence scale. The impact of the respective child's peer group, although lower than that of the child themselves or of the parents, is still considerably high with over half $(56 \%)$ of parents reporting a moderately high to high influence of their child's peer group on the camp enrollment decision.

The child's 4-H club advisors and siblings were moderately influential in choice to participate in 4-H camp. Other childrens' parents were low on the influence scale. The relatively high levels of personal and parental influence on the camp enrollment decision supports earlier findings of Brustad (1988), Huebner \& Mancini (2003), and Mahoney \& Stattin (2000). 
Table 1

Who Influenced the Camp Enrollment Decision

\begin{tabular}{|l|c|c|c|c|c|}
\hline $\begin{array}{c}\text { Factor } \\
(\mathrm{n}=257)\end{array}$ & $\begin{array}{c}\text { No } \\
\text { Influence } \\
1\end{array}$ & 2 & 3 & 4 & $\begin{array}{c}\text { High } \\
\text { Influence } \\
5\end{array}$ \\
\hline My Child & $3 \%$ & $2 \%$ & $5 \%$ & $21 \%$ & $69 \%$ \\
\hline Parents/Guardian & $9 \%$ & $4 \%$ & $12 \%$ & $23 \%$ & $53 \%$ \\
\hline Child's Friends & $19 \%$ & $11 \%$ & $15 \%$ & $25 \%$ & $30 \%$ \\
\hline Advisors & $20 \%$ & $13 \%$ & $20 \%$ & $20 \%$ & $26 \%$ \\
\hline Siblings & $44 \%$ & $8 \%$ & $8 \%$ & $14 \%$ & $26 \%$ \\
\hline Another Parent & $59 \%$ & $7 \%$ & $12 \%$ & $10 \%$ & $12 \%$ \\
\hline
\end{tabular}

2. Are there differences in the nature of influence or the decision to enroll in summer 4-H camps based on child age?

The age of the child had little influence on the nature of influence rating provided by parents related to their respective child's enrollment in 4-H camps. In one category, a significant difference was found with sibling influence, (Table 2). Parents of the oldest campers reported the highest rates of sibling influence on the camp enrollment decision $(p<.05)$. There was not a statistical difference found in influence based on the camper's age of parents, child's friends, advisors, the respective child, or other parents.

Table 2

Differences of Influence of the Camper's Siblings in the Camp Enrollment Decision by Age

\begin{tabular}{|c|c|c|c|}
\hline & $\mathbf{N}$ & Mean & \multirow{4}{*}{$\begin{array}{l}F=3.51 \\
9 \\
(p \leq .05)\end{array}$} \\
\hline Campers 8-10 & 82 & 2.38 & \\
\hline Campers $11-12$ & 47 & 2.49 & \\
\hline Campers 13-15 & 68 & 3.10 & \\
\hline
\end{tabular}

\section{Does the gender predict differences in the nature of significant influence in the camp enrollment decision?}

There was no statistical difference when evaluating the factor of gender. Responses from parents of male and female children indicated similar influence of parents, siblings, child's friends, advisors, the respective child, or other parents in the camp enrollment decision. 
4. Are there differences in the influence of camp enrollment of children based on the alumni status of their parents?

T-tests were run to determine if there was a significant difference in the rated influence of significant groups on the camp enrollment decision based on the alumni status of the respective camper's parent. Parents who were alumni of 4- $\mathrm{H}$ indicated a higher influence on the camp enrollment decision than those who were not $4-\mathrm{H}$ alumni (Table 3, $\mathrm{p}<.05$ ).

Table 3

Difference of Parental Influence on Camp Enrollment Decision

Based on the Parental Alumni Experience with 4-H

\begin{tabular}{|l|c|c|c|}
\hline & N & Mean & $\begin{array}{r}\text { F=5.519 } \\
(\boldsymbol{P} \leq .05)\end{array}$ \\
\hline Non 4-H Alumni Parent & 134 & 3.91 & \\
\hline 4-H Alumni Parent & 117 & 4.22 & \\
\hline
\end{tabular}

T-tests also determined that the rate of influence of other parents was rated higher by those parents who were not 4-H alumni, when compared to those that were alumni of 4-H (Table 4, $\mathrm{p}<.05)$.

Table 4

Difference of Influence of other Parents on Camp Enrollment Decision

Based on the Parental Alumni Experience with 4-H

\begin{tabular}{|l|c|c|c|}
\hline & N & Mean & $\begin{array}{c}\text { F=9.095 } \\
(\boldsymbol{p} \leq .05)\end{array}$ \\
\hline Non 4-H Alumni Parent & 108 & 2.34 & \\
\hline 4-H Alumni Parent & 82 & 1.72 & \\
\hline
\end{tabular}

There was no significant difference found in the influence of siblings, individual child, advisors, or child's friends when comparing groups based on the alumni status of the child's parents.

\section{What methods of marketing are rated most effective in reaching 4-H camp families?}

There are various methods used across Ohio to market 4-H camps to potential campers and their parents. When asked how they learned about 4-H Camp, 56\% found out about camp from their $4-\mathrm{H}$ club advisor, $51 \%$ from a $4-\mathrm{H}$ newsletter, $24 \%$ from a specific $4-\mathrm{H}$ camp mailing, $19 \%$ from the child's friend, and $12 \%$ from another parent (Table 5). 


\section{Table 5}

How Did your Child Learn about 4-H Camp?

\begin{tabular}{|l|l|}
\hline 4-H Volunteer/Advisor & $56 \%$ \\
\hline 4-H Newsletter & $51 \%$ \\
\hline Camp Mailing & $24 \%$ \\
\hline Child's Friend & $19 \%$ \\
\hline Another Parent & $12 \%$ \\
\hline Brochure & $7 \%$ \\
\hline Website & $6 \%$ \\
\hline Newspaper/Radio/TV & $1 \%$ \\
\hline Other & $15 \%$ \\
\hline
\end{tabular}

Respondents were permitted to select more than one option

There are multiple methods to market 4-H camps to particular groups. Parents were asked to evaluate the respective marketing methods that are utilized in terms of their effectiveness. Each mode was evaluated on a Likert-based 5-point scale with 1 being described as "not effective" and 5 described as "very effective." 4-H camp parents rated "Word of Mouth" as the most effective method with $90 \%$ of parents rating it as a 4 or 5 on this scale (Table 6). Other highly rated methods were 4-H club advisors, camp counselors/teen leaders, brochure/flyer, and 4-H newsletter. Mass media methods were not rated as highly as those directly targeted towards parents or those of personal methods. 
Table 6

What is the Most Effective Way to Promote 4-H Camp?

\begin{tabular}{|c|c|c|c|c|c|c|}
\hline \multicolumn{7}{|c|}{$(n=270)$} \\
\hline Method & $\begin{array}{c}\text { Not } \\
\text { Effective } \\
1\end{array}$ & 2 & 3 & 4 & $\begin{array}{c}\text { Very } \\
\text { Effective } \\
5\end{array}$ & $\begin{array}{c}\text { Not } \\
\text { Applicable }\end{array}$ \\
\hline Word of Mouth & $1 \%$ & $2 \%$ & $6 \%$ & $15 \%$ & $75 \%$ & $0 \%$ \\
\hline 4-H Club Advisor & $0 \%$ & $4 \%$ & $5 \%$ & $24 \%$ & $66 \%$ & $1 \%$ \\
\hline Camp Counselors & $2 \%$ & $2 \%$ & $10 \%$ & $28 \%$ & $58 \%$ & $1 \%$ \\
\hline 4-H Newsletter & $1 \%$ & $4 \%$ & $17 \%$ & $24 \%$ & $52 \%$ & $1 \%$ \\
\hline Brochure/Flyer & $2 \%$ & $5 \%$ & $19 \%$ & $33 \%$ & $40 \%$ & $1 \%$ \\
\hline School Visit & $9 \%$ & $14 \%$ & $20 \%$ & $19 \%$ & $27 \%$ & $11 \%$ \\
\hline Mass Mailing & $7 \%$ & $15 \%$ & $25 \%$ & $24 \%$ & $25 \%$ & $4 \%$ \\
\hline Web Site & $9 \%$ & $20 \%$ & $28 \%$ & $20 \%$ & $18 \%$ & $5 \%$ \\
\hline Newspaper & $14 \%$ & $22 \%$ & $25 \%$ & $17 \%$ & $16 \%$ & $6 \%$ \\
\hline TV & $24 \%$ & $19 \%$ & $23 \%$ & $9 \%$ & $10 \%$ & $14 \%$ \\
\hline Radio & $29 \%$ & $26 \%$ & $19 \%$ & $9 \%$ & $7 \%$ & $10 \%$ \\
\hline
\end{tabular}

\section{Implications}

The enrollment decision data found in this study indicates that the decision to enroll in camp is most influenced by the respective 4- $\mathrm{H}$ camper; however parental input is a strong factor in the choice to participate in 4-H camps. This finding is consistent with Howard and Madrigal (1990), who found that parents may serve as a "pre-screener" taking an active role in limiting choices for their children and focusing their opportunities on those that the parents value or can accommodate due to schedule or cost factors. Applying this finding, camp promoters should concentrate their efforts primarily at youth, however keeping in mind that parents tend to first screen and limit choices for their children. Brochures, informational meetings, and general advertisement should have the "child in mind", however should also address the preliminary concerns that parents identify.

When evaluating the nature of the parent's alumni status with 4- $\mathrm{H}$ in terms of the influence on the camp enrollment decision, it was found that parents who are alumni of 4- $\mathrm{H}$ report a higher influence on this process than those parents who are not personally familiar with 4-H. Many parents encourage their children to participate in similar activities that they benefited from 
while a child. They may appreciate the value of the experience; therefore, take a more active role in the final decision to enroll in camp.

Although the overall impact on the decision to enroll in camp from other parents was low, non 4-H alumni parents indicated a higher influence of other parents in the camp enrollment decision. 4-H opportunities may be "foreign" to families that do not have a family history of involvement. These new families may seek out advice and recommendations of other parents who have participated in the past. Those that are alumni have their own past experiences to judge the value and fit of $4-\mathrm{H}$ camping for their respective child.

Although various marketing methods are used to promote the availability of 4-H camping programs to potential youth and their families, personal methods are the most effective. Program planners should pay special attention to the potential of expanding enrollment and reaching additional families through direct channels (youth camp counselors, 4-H camp families, and 4-H club advisors).

Results of this study can provide a framework for other youth serving programs to evaluate the decision of youth to participate and the effectiveness of their marketing techniques in reaching their audiences. With an ever-increasing array of opportunities for youth and their families to participate in, it is important for youth development programmers to be proactive in seeking the feedback of their clientele.

\section{References}

Arnold, M.E., Bourdeau, V.D. \& Nagele, J. (2005). Fun and friendship in the natural world: The impact of Oregon 4-H residential camping programs on girl and boy campers. Journal of Extension, 43,6. Website assessed 10/16/2007, http://www.joe.org

Astroth, K. \& Haynes, G. (2002). More than cows \& cooking: Newest research shows the impact of 4-H. Journal of Extension, 40,4. Website assessed 1/20/2003, http://www.joe.org

Bartko, W. \& Eccles, J. (2003). Adolescent participation in structured and unstructured activities: A person-oriented analysis. Journal of Youth and Adolescence, 32(4), 233-241.

Black, S. (2002). Rethinking peer pressure. American School Board Journal, 189(4). Retrieved December 21, 2006, from: http://www.asbj.com/2002/04/0402research.html

Brustad, R. (1988). Social interactions in coaching your child's team: Harmony or hassle (Part 1). Institute for the Study of Youth Sports. Retrieved May 11, 2002, from: http://edweb3.educ.msu.edu

Castrogiovanni, D. (2001). Adolescence: Change and Continuity. Retrieved December 21, 2006, from: http://www.oberlin.edu/faculty/ndarling/adpeer1.htm

Chappell, V.G. (1994). Marketing Planning for Extension Systems. Journal of Extension, 32; 2. http://www.joe.org 
Deci, E.L. \& Ryan, R.M. (1985). Intrinsic motivation and self determination in human behavior. New York: Plenum.

Eccles, J. \& Harold, R. (1991). Gender differences in sport involvement: Applying the Eccles' Expectancy-Value Model. Journal of Applied Sport Psychology, 3. 7-35.

Eccles, J.S., Wigfield, A., Harold, R.D., \& Blumenfeld, P. (1993). Ontogeny of children's selfperceptions and subjective task values across activity domains during the early elementary school years. Child Development, 64, 830-847.

Fletcher, A., Elder, G., and Mekos, D. (2000). Parental influences on adolescent involvement in community activities. Journal of Research on Adolescence, 10 (1), 29-48.

Garst, B, \& Bruce, F.A. (2003). Identifying 4-H camping outcomes using a standardized evaluation process across multiple 4-H educational centers. Journal of Extension, 41,3. Retrieved October 16, 2007, from: http://www.joe.org

Howard, D., \& Madrigal, R. (1990). Who makes the decision: the parent or the child? The perceived influence of parents and child on the purchase of recreational services. Journal of Leisure Research, 22, 244-258.

Huebner, A. and Mancini, J. (2003). Shaping structured out-of-school time use among youth: The effects of self, family, and friends systems. Journal of Youth and Adolescence 32: 453-463.

Hultsman, W. (1993). The influence of others as a barrier to recreation participation among early adolescents. Journal of Leisure Research, 25 (2) 150-164.

Lamborn, S.D., Brown, B.B., Mounts, N.S. \& Steinberg, L. (1992). Putting school in perspective: The influence of family, peers, extracurricular participation, and part-time work on academic engagement. In F.M. Newman (Ed.), Student engagement and achievement in American secondary schools (pp. 153-191). New York: Teachers College Press.

Laursen, B., Noack, P., Wilder, D. \& Williams, V. (2000). Adolescent perceptions of reciprocity, authority, and closeness in relationships with mothers, fathers, and friends. International Journal of Behavioral Development, 24 (4) 464-471.

Leeds, C.F. (1997). Perceptions of Union County 4-H members about the 4-H program. Thesis, The Ohio State University.

Lingren, Herbert. (1995). "Adolescence and Peer Pressure." Nebraska Cooperative Extension, NF95-211, April 1995.

Mahoney, J., Cairns, B., and Farmer, T. (2003). Promoting interpersonal competence and educational success through extracurricular activity participation. Journal of Educational Psychology 95(2): 409-418.

Mahoney, J., and Stattin, H. (2000). Leisure activities and adolescent antisocial behavior: The role of structure and social context. Journal of Adolescence 23: 13-27. 
Ohio State University Extension (2005). Ohio 4-H statistical report. Retrieved December 21, 2006 from: http://www.ohio4h.org/about/statistics.html

Ohio State University Extension (2003 - 2007). Ohio 4-H Youth Enrollment Program: ES- 237 Report. Retrieved November, 2007, from: http://www.ohio4h.org/blueribbon/contact.html

Raymore, L., Godbey, G., and Crawford, D. (1994). Self esteem, gender and socioeconomic status: Their relation to perceptions of constraints on leisure among adolescents. Journal of Leisure Research 26: 99-118.

Rennekamp, R. (1990). Influences on teen decisions. Journal of Extension, 28,3. Retrieved April 21, 2002, from: http://www.joe.org

Skelly, J. (2005). Social Marketing: Meeting the Outreach Challenges of Today. Journal of Extension, 43,1. http://www.joe.org.

Thompson, P.L. (1998). Factors related to the retention of Ohio teen 4-H members. Thesis, The Ohio State University.

United States Department of Agriculture (2005). Annual 4-H Youth Development Enrollment Report. Retrieved December 21, 2006, from: http://www.reeis.usda.gov/

Wingenbaugh, G., Nestor, C., Lawrence, L., Gartin, S., Woloshuk, J., \& Mulken, P. (2000). Marketing strategies for Recruiting 4-H members in West Virgininia. Journal of Agricultural Education, 41 (1) 88-94.

(C) Copyright of Journal of Youth Development Bridging Research and Practice. Content may not be copied or emailed to multiple sites or posted to a listserv without copyright holder's express written permission. However, users may print, download or email articles for individual use. 